\title{
The Replication and Excess of Disciplinary Power in Sekigun and Aum Shinrikyo - A Foucaultian Approach
}

\author{
Philip N. Eate \\ University of Adelaide
}

\begin{abstract}
This article aims to explain why both the left wing extremist group Sekigun (Red Army) and the new religious sect Aum Shinrikyo (The Supreme Truth of Aum) adopted violent and deadly forms of disciplinary power in their pursuit of an idealistic society.

The approach in this article differs from the existing literature in that it is mainly concerned with why both groups failed to provide a more preferable alternative to the existing state structure and finally internalised their violence, torturing their own members.

Foucaultian theory will be utilised in order to analyse the role that hierarchy and hierarchical surveillance played in re-enforcing the harsh discipline and training methods used by both groups. In this approach this article will show that despite the efforts of both Sekigun and Aum Shinrikyo to create the antithesis to everything they rejected within Japanese society they each paradoxically reproduced and magnified within their own social organisations the least desirable societal traits of elitism, exclusivity and conformity using the most extreme disciplinary measures to do so.
\end{abstract}

\section{Keywords}

Sekigun, Aum Shinrikyo, Foucault, Discipline, Surveillance

\section{Introduction}

This article deals with the replication of modes of disciplinary power in the left-wing extremist group Sekigun (Red Army) and the new religious sect, Aum Shinrikyo (The Supreme Truth of Aum), focusing on the organizational structure of both groups and how they mirrored those found in mainstream Japanese society. 
.

It is the contention of this article that both Sekigun and the Aum Shinrikyo replicated characteristics prominent in Japanese society-such as elitism, competitiveness and the tendency to exclude those who do not conform to the conventions of the group - and perpetuated these further. It will argue that while those who joined either Sekigun or Aum Shinrikyo had their own personal motives for doing so and brought with them certain needs and expectations which they believed the groups could fulfil, both Sekigun and Aum Shinrikyo ultimately failed to produce the sort of societies that their members had hoped for; the torture-killings of a number of members from each group serve as a motif for how far both groups had strayed from their original goals.

Foucaultian theory will be utilized in order to analyze the role that hierarchy and hierarchical surveillance played in re-enforcing the harsh discipline and training methods used by both groups. In this approach this article seeks to illustrate how these young people's efforts to resist the conventional institutions of Japanese society - which they viewed as oppressive, alienating, and exclusive - led them to join new groups which ended up to be more closed and totalitarian than the one they had left.

\section{The Asama-sanso Incident}

In December 1971 Sekigun, a small left-wing extremist organization, retreated to an isolated mountain hideout in the Japanese Alps of Gunma prefecture to take part in joint military exercises with a second revolutionary group. In the aftermath of what was dubbed in the Japanese media as the Asama-sanso ${ }^{1}$ Incident, police interrogations revealed the details of violent purges that had been carried out at the hideout. ${ }^{2}$ According to those involved, the first death was accidental. Sekigun's leader, Mori Tsuneo, had become displeased with the progress of the training of one member, Ozaki Atsuo, and decided that he needed to engage in a boxing match with a much stronger opponent in order to 'toughen him up' into a real revolutionary fighter. ${ }^{3}$ Over the next two days Ozaki was left tied upright to a doorpost and beaten intermittently by the other group members. ${ }^{4}$ Mori later checked Ozaki and found him to be unable to make a sokatsu - a form of self-assessment summarizing one's personal shortcomings commonly employed by left-wing organizations - as a result of the beatings. He declared that Ozaki had not yet achieved total 'communist transformation's and ordered that Ozaki be beaten again. When Ozaki was checked later to submit his sokatsu he was found dead. ${ }^{6}$ In the days that followed Ozaki's death, eleven others would be killed in a similar fashion.

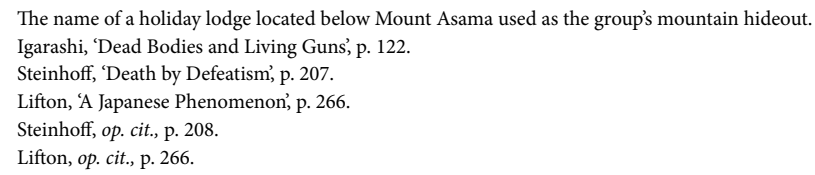




\section{The Aum Affair}

In March 1995, five disciples of the religious sect, Aum Shinrikyo, under order of their guru, Asahara Shoko, released sarin poison gas on the Tokyo Subway killing twelve people and injuring as many as 5,000 more. ${ }^{7}$ Police investigation would later reveal, however, that this was neither the first nor the last of such acts committed by the sect. These acts of violence ranged from the murders of public opponents of the group, to beatings of members inside the movement, and the secret disposal of bodies of followers who had died accidentally as a result of Aum's harsh ascetic practices. ${ }^{8}$ The first death - that of Aum disciple Majima Terayuki - occurred in mid-1988 as a consequence of one of the group's austere training procedures. ${ }^{9}$ The practice undertaken by Majima was that of inverted suspension: having one's legs bound by rope and hung upside down for intervals exceeding 90 minutes ${ }^{10}$ interspersed by immersion into extremely cold water, resulting in Majima’s case, in shock and subsequent death. ${ }^{11}$

\section{Commonalities between Sekigun and Aum Shinrikyo}

Sekigun represented what was perhaps the most extreme element of the Japanese student movements of the 1960s. ${ }^{12}$ The group differentiated itself from other groups in existence at the time through its advocacy of armed revolution as a means to toppling what they perceived to be the combined oppression and exploitation by the Japanese state and the international bourgeoisie. ${ }^{13}$ So as to overcome their own latent bourgeois propensities and prove their commitment to the cause of revolution, Sekigun's members took part in Spartan training exercises and self-reflection meetings, which eventually escalated into the torture-killings of twelve of their comrades. ${ }^{14}$

Aum Shinrikyo, on the other hand, was one of the many new religious sects of the 1980s. The group was notable for attracting a high percentage of young people often idealistic yet frustrated with the pressures and materialistic values of 'progress' and 'rationalism' existent in contemporary Japanese society. ${ }^{15}$ Aum also stood apart from most other Japanese religious movements by insisting that its members renounce the world by giving up their material possessions, leaving their families, and joining the Aum

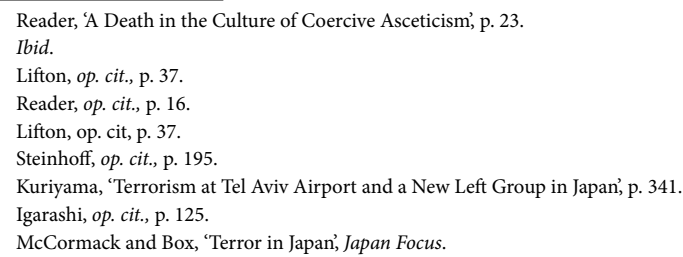


.

commune. ${ }^{16}$ Here they would focus entirely on their spiritual practice and undertake austerities so as to remove from themselves the negative karma that was supposedly the cause of their individual suffering but also the source of so many of Japan's social problems. ${ }^{17}$ To this end, Aum disciples, under the guidance of the sect's guru, Asahara Shoko, submitted themselves to extremely harsh forms of physical training that often crossed the line between discipline and torture ${ }^{18}$ in the hope of becoming spiritually superior to those outside of the commune. These practices, however, would eventually culminate in the deaths of several Aum members.

Both Sekigun and Aum Shinrikyo share a number of commonalities which make studying them within a comparative framework feasible: both groups attracted idealistic young people, usually university students, who were concerned with the deep social, political, and moral problems produced by the narrowly focused, conservative Japanese state; ${ }^{19}$ both Sekigun and Aum Shinrikyo featured vertically organized social structures mirroring the elitist hierarchical structuring of contemporary Japanese society; members of both Sekigun and Aum Shinrikyo came to view themselves as revolutionary and spiritual elites respectively, physically isolated themselves from the rest of mainstream society, and undertook harsh corporal training exercises to further confirm their place as the rightful future leaders of Japan; ${ }^{20}$ finally, in both groups, violence towards their own members as well as acts of terror directed at the public came to be legitimized by the purity of their purpose. ${ }^{21}$

\section{The Organization: Hierarchy, Authority, Discipline and Correct Training}

It is important that we address the origins of the hierarchical organizational structures adopted by both Sekigun and Aum Shinrikyo here because it illustrates the degree to which both groups developed into highly authoritarian organizations that exerted extreme disciplinary measures on their members.

Sekigun and Aum Shinrikyo shared a similar hierarchical organisational structure. While the ideologies behind this organisation might have differed for each group, the end results were very similar: strong vertical links between members representing status within the group, yet at the same time, relatively weak horizontal relations between members.

\footnotetext{
Reader, 'Creation, Preservation and Destruction', p. 82.

Lifton, 'Crossing the Threshold', p. 204.

Lifton, "The Guru and His Cult", p. 27.

McCormack and Box, op. cit.

Igarashi, op. cit., p. 125.

McCormack and Box, op. cit.
} 


\section{Organisational Structure and Hierarchy in Sekigun - Democratic Centralism}

As a splinter-faction originally associated with the Communist League which itself was initially part of the Japanese Communist Party-dominated Zengakuren, ${ }^{22}$ Sekigun based its vertical command structure on the communist system of democratic centralism. ${ }^{23}$ This system is an arrangement whereby each level of an organization elects representatives to the decision-making body at the next highest level. ${ }^{24}$ As representatives at each level are chosen on the basis of their support at the level beneath them - and hence have a certain established power base behind them - policy conflicts between representatives tend to result in factionalism. ${ }^{25}$ It was as a result of this propensity for factionalism that Sekigun was forced to split from the Communist League in 1969.

Immediately after its inception, Sekigun reproduced the same type of communist vertical organisational structure complete with formal representation for regional and local units and final decision-making power concentrated in the hands of the highest level central committee. ${ }^{26}$ Thus, from the very beginning there was a clear sense of vertical hierarchy in Sekigun. Although the internal relations of the elected central committee were initially loose and egalitarian with the relationship between the committee and the larger membership beneath not clearly defined, ${ }^{27}$ after a series of failed 'military' operations which facilitated the arrests of many of the group's members - including six of the original seven representatives of the central committee - Sekigun came under the leadership of Mori Tsuneo, who would transform it into a highly autocratic organization. ${ }^{28}$

\section{Autocratic Organization}

Under Mori, the remaining Sekigun membership was reorganized in an effort to further militarize the group. ${ }^{29}$ It still maintained its vertical command structure, however. Mori remained at the head of the group whilst directly beneath him a small circle of his closest associates formed the new central committee. ${ }^{30}$ The egalitarian process of debating strategies which had existed previously was also abandoned in favour of a

\footnotetext{
22 The Zengakuren (an acronym for Zen Nihon Gakusei Jichikai Sourengou or 'All-Japan Federation of Student Self-Governing Associations' was the federation of student government associations in Japan. It emerged in 1948 with close ties to the Japanese Communist Party (JCP), however, as a result of conflict over issues of ideology the Zengakuren began to fragment into a number of factions opposed to the JCP throughout the 1960s. For further discussion see for instance Fuse, 'Student Radicalism in Japan', pp. 325 - 342 and Steinhoff, 'Student Conflict'.

23 Steinhoff, "Hijackers, Bombers and Bank Robbers', p. 726.

24 Steinhoff, "Student Conflict", p. 178.

Ibid., p. 179.

Ibid.

Steinhoff, 'Hijackers, Bombers and Bank Robbers', p. 726

Steinhoff, 'Three Women Who Loved the Left', p. 310.

Igarashi, op. cit., p. 132

Steinhoff, 'Death by Defeatism', p. 197.
} 
more hierarchical flow of orders between different levels - something justified as being appropriate for an 'army' in which 'soldiers' obey orders. ${ }^{31}$ Initially, Mori's determination to militarize Sekigun led to the group's undertaking of a series of bank robberies which, though successful, placed them under increasing pressure from police and alienated the general public as well as some of Sekigun's own members. ${ }^{32}$

\section{Merging Two Organizations}

By 1971, in an effort to form an armed revolutionary army, Sekigun was forced into a merger with another left-wing extremist group in operation at the time, the KAK (Keihin Ampo Kyoto, also known as Tokyo-Yokohama Joint Struggle against Japan-U.S. Security Treaty ${ }^{33}$ ), which had obtained a cache of firearms and ammunition through a series of gun shop robberies and police box raids but was short of money - a commodity which Sekigun now had in abundance. ${ }^{34}$ The KAK had moved into an abandoned cabin in the Japanese Alps and asked supporters to join them. While Mori was not interested in retreating into the mountains entirely, he saw the KAK's weapons and large membership as valuable assets.

\section{Group Structure of the KAK}

Just like Sekigun, the KAK was a product of the many schisms common within the student movement at the time, however, the KAK differed from Sekigun in that it was more ideologically Maoist and nationalistically anti-American ${ }^{35}$ Furthermore, its radical feminist position had attracted a greater number of women to the group. Compared to Sekigun, the KAK though hierarchical, was also characterized by somewhat stronger horizontal connections between its members. ${ }^{36}$ Nonetheless, the group did have a central leadership headed by Nagata Hiroko. ${ }^{37}$ As in Mori's case, leadership of the KAK had fallen into Nagata's hands as a result of a series of arrests which both decimated the ranks of the organisation and placed its original leader in prison. ${ }^{38}$

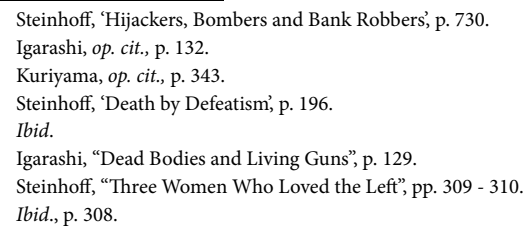




\section{Organizational Fusion - Rengo Sekigun (United Red Army)}

The relatively similar organizational structures enabled the two groups to create a unified leadership between Mori's central committee and Nagata's leadership group. ${ }^{39}$ Although Mori attempted to give the illusion that he and Nagata were equals, it was clear from the outset that he was in charge and Nagata willingly deferred to him.

\section{The New Hierarchy}

The new group dubbed Rengo Sekigun (United Red Army) was, thus, noticeably hierarchical; Mori was first in command with Nagata just below him. Beneath them, a central committee was formed of their most trusted associates; and under the command of this committee was a core membership which included a number of 'soldiers' from both factions who had been underground for a number of months. Both groups had also brought to Rengo Sekigun a number of members who had had no underground experience. In the KAK's case this included a substantial group of women and even some children ${ }^{40}$ reinforcing a social order founded not only on who could muster the biggest support base, but also on practical 'military' experience. Consequently, those who wanted to become 'real soldiers' had to prove themselves and their commitment to the group - or more specifically, gain Mori's approval. One could be accepted by the Rengo Sekigun leadership and essentially move up the pecking order in a number of ways. These included volunteering for missions or giving a sokatsu - a sort of critical self-assessment commonly used in communist organizations. The ability to improve one's status through proving one's commitment to the group will be explored in further detail later.

To briefly summarize, Sekigun had adopted strong vertical organization right from the movement's inception basing its organizational structure on the system of communist democratic centralism. Under Mori's leadership, this command structure only became more autocratic. After Sekigun merged with the KAK - a similarly hierarchically ordered organization - the group retained its vertical chain of command and simply assimilated the KAK membership into the existing organizational structure, albeit under the new name of Rengo Sekigun.

Now this article will turn to the origins of Aum Shinrikyo's organizational structure and how it developed a complex, stratified social hierarchy which mirrored not only the one established within Sekigun, but which can be found in Japanese society generally. 
.

\section{Spiritual Hierarchy in Aum Shinrikyo - Shukke (renunciants) and Zaike (lay members)}

Similarly to Sekigun, shortly after the establishment of Aum Shinrikyo, the sect adopted a vertical organizational structure which ranked its members according to stages of spiritual attainment. This hierarchical structure began to emerge in September 1986 when Aum's guru Asahara Shoko and his followers formed a sangha, a type of Buddhist monastic community in which those who want to commit themselves totally to their religious practice could be 'free of all attachments and worldly ways." ${ }^{41}$ This created an immediate distinction between those who had moved to the sangha as shukke (renunciants, or literally 'left home') and zaike (lay members) those unable or unwilling to do so. Although the sect later provided a special course for zaike who still wanted to practice their spiritual beliefs in the secular world and reach a state close to Buddhahood, it was believed within Aum that only those who had truly renounced the world and had become shukke could ever reach the highest levels of spiritual enlightenment and attain gedatsu (liberation). ${ }^{42}$ Thus, while the value that Aum Shinrikyo placed on renunciation of the secular world was founded in their interpretation of Buddhist monasticism ${ }^{43}$ it also established the first distinct stratum in the group's internal hierarchical structure by awarding shukke a higher social status than zaike within Aum.

\section{Hierarchy Within the Sangha (Monastic Community)}

The Aum Elite: As more people joined the sangha so an increasingly complex hierarchical social structure began to emerge with names, clothing and symbols associated with each rank. At the top of this hierarchy was Asahara himself. As the only person to have attained ultimate liberation, Asahara was regarded by his followers as the 'victor of truth $^{34}$ and consequently held the rank of 'ultimate liberated master ${ }^{25}$ meaning that Asahara alone could wear the purple robes symbolising his level of spiritual perfection. Beneath Asahara were four levels of Aum shi (masters): the highest rank was seitaishi or sacred grand master who wore green tunics; below these were the seigoshi (sacred awakened masters) who wore red tunics; and beneath them the shi and shiho or teacher and assistant teacher respectively - both ranks wearing different styles of white clothing. ${ }^{46}$ The seitaishi, seigoshi and shi constituted Aum's spiritual elite ${ }^{47}$ who, as well as being granted the title of 'master', were also bestowed with individual 'holy names'

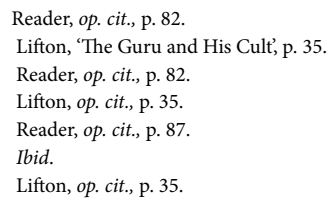


selected by Asahara further marking them as the guru's 'chosen' elite. ${ }^{48}$

Aum's Novices: Just as the highest ranking members of the sangha were organized hierarchically according to their level of spiritual attainment, so too were the lowest ranking shukke, known in Aum as samana - a Sanskrit word for one who has renounced the secular world - divided into ranks. ${ }^{49}$ The lowest ranking samana tended to be the newest members of the sangha and were automatically classed as samana novices. This group of junior disciples could be clearly differentiated from the other samana by their orange robes. The higher ranking samana and samanacho (head samana) wore the same style of white robes although samanacho differed from lower members in that Asahara had given them their own holy name. It is interesting to note the way in which the lowest Aum members, the samana novices, were clearly signified as being at the bottom of Aum's spiritual hierarchy by their orange robes. They were at least considered a part of the sangha community, however; the zaike who had not yet joined the sangha on the other hand were eventually viewed by Asahara dismissively as okyakusama (guests). ${ }^{50}$

Thus, Aum's hierarchical organizational structure was intrinsically linked to a spiritual hierarchy, which ranked members according to their supposed level of spiritual achievement. On the surface this might seem ironic given that those who chose to join the sangha did so to renounce the society they viewed as competitive, status-conscious and materialistic. To understand why these individuals willingly took part in an equally hierarchical and status-conscious culture within the Aum commune, however, we must look at the group's reasoning behind adopting such an organizational system.

\section{Aum's Hierarchy as a Process of 'Liberation' - Defining Aum's Objectives}

Aum's primary objective was to bring salvation in the form of gedatsu (liberation) to as many people as possible before a final world-ending cataclysm which Asahara had prophesised would take place at the end of the $20^{\text {th }}$ Century. While many were attracted to Aum by the idea of attaining gedatsu it remained a vaguely defined concept. Indeed, for Aum, the difficulty of demonstrating gedatsu became a major predicament; the sect had after all encouraged people to give up their families, possessions and social status with the promise that attaining gedatsu was possible. ${ }^{51}$ Clearly defining what gedatsu was and the stages through which one had to proceed in order to attain it became a pressing

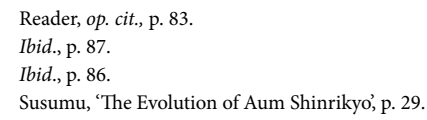


.

issue for Asahara as many shukke began to feel uncertain about their spiritual progress. ${ }^{52}$ Establishing clear guidelines for the process of gedatsu therefore was paramount in retaining Aum membership.

\section{The Stages of Gedatsu and the Spiritual Hierarchy}

In 1987, Asahara established a hierarchical (loosely Buddhist) cosmology which postulated that above the material world of humans there were two higher realms - the Astral realm and the Causal realm - each of which being subdivided into lower, middle and upper regions. Corresponding to each region of this cosmological system were specific types of yoga, which once mastered, allowed one to ascend through the various realms during meditation. ${ }^{53}$ Reaching the highest realm, or Maha Nirvana, correlated to the attainment of gedatsu.

Each of these correlative relations between cosmological realms and yogic practices were referred to in Aum as stages (suteji) ${ }^{54}$ which Asahara claimed one moved up through to achieve 'the ultimate state. ${ }^{55}$ As each realm had different characteristics, only Asahara - the 'ultimate liberated master' - could divine whether a disciple had reached a higher level of practice based on their accounts of what they had seen whilst meditating. ${ }^{56}$ Completion of each stage meant that the disciple was one step closer to reaching gedatsu, however, it also granted more earthly rewards: promotion to a higher rank, different coloured garments or the appellation of a holy name. Thus, Asahara had not only developed a hierarchical cosmology for Aum, but a framework in which disciples could gauge their level of progress up the spiritual hierarchy. ${ }^{57}$

To summarize, Aum's system of organizational and spiritual stratification actually emerged out of what the sect saw to be the necessity to 'save' as many people as possible. ${ }^{58}$ Although the spiritual hierarchy which Asahara conceptualised was initially intended to serve as a guide for a process of spiritual development which otherwise would have been difficult to comprehend, the process of liberation itself ultimately perpetuated the existing vertical organization structure.

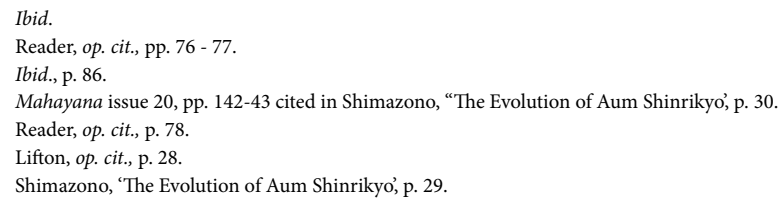




\section{The Duplication of Patterns of Japanese Organisational Structure}

Strong vertical organization, social stratification, high status consciousness and competitiveness, and a disregard for outsiders have generally been perceived as the hallmarks of Japanese social organization..$^{59}$ Sekigun and Aum Shinrikyo were established to provide an alternative to what those who joined believed were the endemic problems found in Japanese society. The examination of the organisational structures and the ideological/spiritual structures which supported them, however, indicates that clear parallels can be drawn not only between Sekigun and Aum but also between both groups and Japanese society in general. As discussed above, Sekigun was a product of the Japanese student movement - a group which opposed the autocratic, authoritarian power of the Japanese state and cited the hierarchical organization of tertiary education as some of the main reasons for their discontent. Thus, in opposing these power structures which in their view existed solely to benefit the elite members of the ruling 'bourgeoisie' class, ${ }^{60}$ their fundamental ideological inclinations were towards the pursuit of greater social equality and freedom from oppression. ${ }^{61}$ On the other hand, Aum Shinrikyo was supposedly established by those who opposed the emptiness created by the materialistic competitiveness and social stratification of contemporary Japanese society. ${ }^{62}$ The analysis of the organizational patterns of Sekigun and Aum presented above, however, suggests that contrary to their oppositionist stances towards various aspects of Japanese society, and especially its hierarchical structure, these groups were indeed rigidly vertically organized, highly stratified, with tendencies towards authoritarianism.

\section{The Early Stages of Authoritarian Control}

In addition to establishing complex hierarchical structures that reinforced vertical relations between members of different status, both groups also adopted deliberate strategies to weaken horizontal relations between members of the same status. In both Sekigun and Aum, members were often physically separated from one another or turned against each other in an effort to assure both their loyalty to the greater cause of the group and submission to the hierarchical order. This was certainly the case in Sekigun for Kato Yoshitaka and Kojima Kazuko and the same can be said of former Aum disciple Masutani Hajime. These cases will now be discussed in sequence to illustrate the stringency of the social order adopted by both groups and the extent to which horizontal relations were undermined.

\footnotetext{
59 For references to social stratification and high status consciousness see for instance Mohwald, 'Social Stratification'; Bestor, 'Conflict, Legitimacy and Tradition in a Tokyo Neighbourhood'; Steinhoff, 'Death by Defeatism and Other Fables'. For references to competition see for instance Vogel, 'Examination Hell', pp. 40-67 and Sugimoto, 'Diversity and Unity in Education'. For reference to the exclusion of outsiders, see Ishida, 'Conflict and Its Accommodation'. 60 Igarashi, 'Dead Bodies and Living Guns', p. 25.

61 Steinhoff, 'Portrait of a Terrorist', pp. $830-831$.

62 Reader, op. cit., p. 86.
} 
.n.m.n. of

'To select and to levy's3 - The case of Kato Yoshitaka and Kojima Kazuko

After retreating to an abandoned cabin deep in the Japanese Alps, Mori decided that the members of Sekigun and the KAK should undergo joint training exercises as a type of 'unification ritual' ${ }^{64}$ designed to fuse the separate factions together into one revolutionary militia. Whilst this process was initially envisaged as a sort of team bonding exercise, the result did not so much bring together the members of both groups as divide individual members. An illustration of this can be found in KAK members Kato Yoshitaka and Kojima Kazuko, who Mori decided were not fully committed to the group and thus needed to undergo 'communist transformation. ${ }^{65}$

Nagata - who later stated that she was ashamed that followers might appear less revolutionary to Mori - fully endorsed whatever measures he proposed in order to bring about Kato's and Kojima's communist transformation. Subsequently, Nagata suggested that Kato and Kojima be put together at a writing desk so that they could prepare their sokatsu - a critical self-analysis outlining personal failings and how they intended to correct them. Mori, quickly irritated by their lack of progress, ordered the pair separated and then increased their restrictions further; forcing them to kneel in a formal Japanese posture, denying them food and, most significantly, prohibiting their communication with other group members. ${ }^{66}$ Regardless of the intended outcome of these restrictions, Mori effectively isolated Kato and Kojima from one another as well as from others in the group, thus weakening the links between them and their comrades and reiterating the new pecking order within Rengo Sekigun.

\section{Celibacy as an Act of Revolution}

In the middle of the night, Kojima accused Kato of molesting her whilst she had been sleeping. Although both Nagata and Mori were outraged, they were not so much concerned about the claim of sexual misconduct itself as they were with the fact that Kojima and Kato - who were supposed to be focusing on their communist transformation - were distracted by private emotions. ${ }^{67}$ Subsequently, Mori ordered the pair beaten by the rest of the group, Kojima being included in the beating because Mori thought she was attempting to portray herself as a 'martyred heroine.68 ${ }^{68}$ The beatings ultimately produced further sexual confessions from Kojima and Kato who,

\footnotetext{
Foucault, 'The Means of Correct Training', p. 170.

Steinhoff, 'Death by Defeatism and Other Fables', p. 197.

Ibid., p. 204

Ibid.

Ibid.

68 Ibid., p. 224.
} 
in giving such candid sokatsu, probably thought that they were making progress with their communist transformation. Communist transformation, much like the notion of gedatsu for Aum Shinrikyo however, was a vague, poorly defined concept; attainment of which being largely dependent upon Mori's own satisfaction that communisation had been achieved. ${ }^{69}$

Despite Mori's view that romantic relations were a distraction from revolutionary ambitions, marriage between members of Sekigun as well as members of the KAK was not uncommon - Nagata was already married to KAK member Sakaguchi Hiroshi before the group's merger with Sekigun - and nor were such unions prohibited - Mori, most notably, suggested that he and Nagata be married to strengthen the merged group's leadership image. These relationships differed from others, it was argued, because they served to further the cause of revolution rather than personal or selfish (i.e. bourgeois) desires. Consequently, relations between members - that is, horizontal rather than vertical relations - that went beyond simple camaraderie ran the risk of being viewed by Rengo Sekigun's central committee as self-indulgent and not in keeping with the spirit of selfless submission to the cause of revolution required of revolutionary elite.

Similarly, the very nature of Aum Shinrikyo's introspective spiritual practice - aimed at self-transformation and the individual realization of gedatsu weakened horizontal relations between shukke, strengthening Asahara's authority over the group as a whole. ${ }^{70}$ This manifests most clearly in the example of Masutani Hajime.

\section{'Making individuals' - The case of Masutani Hajime}

On Asahara's return from northern India in 1987 he introduced to Aum's training system what he claimed to be a Tibetan Buddhist ascetic practice known as 'practice in solitary confinement. ${ }^{71}$ According to former sect member Masutani Hajime, solitary confinement was often utilized to isolate those who were 'wavering in their faith or were no longer useful to Aum' but also to discipline shukke who had developed relationships with other members which were deemed inappropriate. ${ }^{72}$ Masutani claims that in 1993 he was placed in solitary confinement hooked up to a polygraph machine and interrogated about his relationship with another disciple: 'I was... asked all sorts of questions, including some unpleasant ones I couldn't accept. ${ }^{73}$ Before this incident, Masutani had expressed his doubts about some of Aum's practices to fellow members:

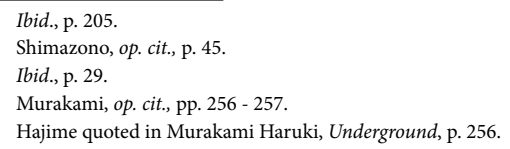


.

I felt that maybe everybody felt the same way... but they'd cut me off saying, 'You think that way because of your uncleanliness' or 'That's karma', which means that whenever any doubts came to mind everything could be blamed on your own uncleanliness. Similarly all good things were 'Thanks to the guru." ${ }^{\text {'4 }}$

The impression given of life in the sangha is one in which personal relationships were policed by higher ranked shukke and where it was virtually impossible to confide in fellow disciples without being judged. Thus, we can see from Masutani's testimony, that extreme methods of individualization of personal faults functioned to erode horizontal relations between disciples; physically and socially isolating them from one another by breaking down the camaraderie among members of equal ranking. Moreover, the constant criticism of each other's supposed spiritual imperfections reinforced Aum Shinrikyo's spiritual hierarchy, strengthening the vertical command structure.

\section{The Authority Structure of Sekigun and Aum Shinrikyo}

The deliberate and systematic weakening of horizontal ties between individual members in both Sekigun and Aum Shinrikyo also prevented the development of independent groups within both organizations, which could have kept the authority of Mori and Asahara in check. Instead, the organizational structures of both groups fostered a certain degree of incohesiveness among members. ${ }^{75}$ These strong vertical command structures coupled with relatively weak horizontal ties between members created the optimum conditions for a system of discipline through surveillance to prevail - a system of power which lends itself well to a Foucaultian analysis.

\section{Discipline and Surveillance - a Foucaultian Approach}

Foucault's theory of discipline and surveillance explains the methods by which networks of power are utilized to survey, train and discipline individuals so as to mould them into the desired form. ${ }^{76}$ As Foucault writes:

The chief function of the disciplinary power is to train rather than to select and levy; or, no doubt, to train in order to levy and select all the more. It does not link forces together in order to reduce them; it seeks to bind them together in such a way as to multiply and use them...It 'trains' the moving, confused, useless multitudes of bodies and forces into a multiplicity of individual elements - small, separate cells,

\footnotetext{
Ibid., p. 255.

Shimazono, op. cit., p. 44

Foucault, 'The Means of Correct Training', p. 170.
} 
organic autonomies, genetic identities and combinatory segments. ${ }^{77}$

Key to establishing such discipline is 1) 'the art of distributions', and 2) 'hierarchical observation. ${ }^{\text {78 }}$

The Art of Distributions - Enclosure, Partitioning and Rank

In the first instance, discipline proceeds from the distribution of individuals in space and achieves this end by employing a number of techniques, including what Foucault refers to as enclosure, partitioning and rank. ${ }^{79}$

Enclosure: Discipline requires 'enclosure'; the specification of a place heterogeneous to all others and closed in upon itself. It is in Foucault's words 'the protected place of disciplinary monotony. ${ }^{80}$ Both Sekigun and Aum possessed such enclosed places in the form of their remote mountain hideout and sangha respectively. Enclosure is a necessary but insufficient condition in the institution of the disciplinary structure, however.

Partitioning: Discipline also necessitates partitioning; a method of 'breaking up the collective dispositions' ${ }^{81}$ and a tactic of anti-concentration which allows for the supervision of each individual so as that it may be assessed, judged, and have its qualities and merits calculated. ${ }^{82}$ Partitioning was used in the disciplining of Kato and Kojima when Mori ordered their separation - from the rest of the group and each other - and then restricted them from communicating with their comrades. ${ }^{83}$ It was also utilized by Aum in its 'solitary confinement training', as illustrated in the case of Masutani who was isolated so that he may be interrogated and assessed by his superiors.

Rank: Lastly, Foucault argues that discipline is an art of rank, a technique for the transformation of arrangements, individualizing bodies by a location that does not give them a fixed position, but distributes them and circulates them in a network of relations. ${ }^{85}$ In this social order each individual according to its age, performance, and behaviour occupies sometimes one rank, sometimes another; the individual constantly moving over a series of compartments, some of which may be considered

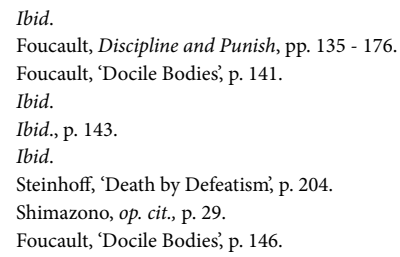


.

ideal compartments, marking a hierarchy of ability or knowledge, whilst others express the distribution of values or merits within the space of an organization. It is a perpetual movement in which individuals replace one another in a space marked off by intervals. ${ }^{86}$ In Sekigun, as in Aum, rank was fluid - one's ranking or status within each organization could be improved according to one's ability or what one contributed to the group. Rank, however, was also assessed and allocated from above by the respective organizations' leaders creating a vertical chain of command that allowed for the implementation of control through hierarchy. It should also be acknowledged that rank functioned beyond the perimeter of each group's respective compounds.

To summarize, the art of distributions specifies the organisation of enclosures, partitions and ranks, creating complex spaces that are simultaneously architectural, functional and hierarchical. As Foucault states: 'they are mixed spaces: real because they govern the disposition of buildings [and] rooms...but also ideal, because they are projected over this arrangement of characterizations, assessments, [and] hierarchies. ${ }^{87}$ Aspects of this 'art' were instrumental in the forms of organizational control implemented in both Sekigun and Aum Shinrikyo. Physical separation from the outside world coupled with the deliberate isolation of individual members enabled the leadership of both organizations to enforce total control over their respective memberships. The arranging of individuals into ranks allowed for even greater control by further eroding relationships between individuals and creating partitions of hierarchy between them that existed beyond the physical confines of the mountain hideout or monastic commune.

\section{Hierarchical Observation}

Foucault also discusses what he terms 'the means of correct training', or, 'surveillance as a method of discipline through coercion' ${ }^{88}$ This method can be seen to be employed by a range of institutions - prisons, schools, armies, hospitals - and applied to a variety of cultural objects: parents, children, students, soldiers, patients and so forth ${ }^{89}$ It follows from Foucault's discussion of the art of distributions that surveillance as a method of discipline requires the generation of spaces which are architectural, functional and hierarchical in order to be successful.

Hierarchy as a network of power: surveillance requires the creation of 'real' spaces - for instance, the architecture of the school or prison building must be conducive to the continued surveillance of its occupants by the disciplinary power; but inside this real

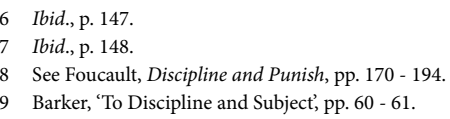


space, discipline also utilizes relays - integrated into the disciplinary apparatus so as to increase its effects ${ }^{90}$ - establishing a system of hierarchical observation. Foucault writes, by means of such a system of surveillance, disciplinary power becomes an integrated system which although resting on the individual, functions as a network of relations from top to bottom, but also to a certain extent from bottom to top and laterally.91 This network of power holds the whole together and traverses it in its entirety with effects that derive from one another: the supervisors perpetually supervised. ${ }^{92}$

Hierarchical surveillance as pedagogy: accordingly a form of reciprocal, hierarchized surveillance is inscribed at the heart of teaching, not as an additional or adjacent part, but as a mechanism that is inherent to it and which increases its efficiency.9. Foucault gives the example of the $17^{\text {th }}$ Century classroom in which the assistant teacher taught the pupils the correct way of holding the pen, corrected mistakes whilst taking note of trouble makers; the head boy in each class would make sure that the pupils recited their lessons and marked down those who did not know them; and above these the intendant supervised all, was in charge of behaviour and also initiated newcomers into the customs of the school ${ }^{94}$. In other words, the functions of surveillance are duplicated by a pedagogical role; three procedures are integrated into a single mechanism: the teaching proper, the acquisition of knowledge by the very nature of the pedagogical activity, and a reciprocal, hierarchical observation..$^{95}$

Hierarchy and pedagogy in Aum: There are clear similarities here with the organisational structure and roles of members in Aum; just as the school in Foucault's example had its ranks of intendant, assistant teacher and head boy, so too the Aum sangha had its shi (master/teacher), shiho (assistant teacher) and samanacho (head samana); each position having a pedagogical role but also operating as supervisors and discipliners. As Lifton also notes, Aum had a hierarchy of mystical manipulators, each disciple being under another's authority, reaching up to the guru himself. ${ }^{96}$

Both groups already featured highly developed hierarchical structures making hierarchical surveillance possible. Let us now turn to another aspect of the social stratification within both Sekigun and Aum Shinrikyo.

It is a common misconception that Sekigun and Aum Shinrikyo were constituted

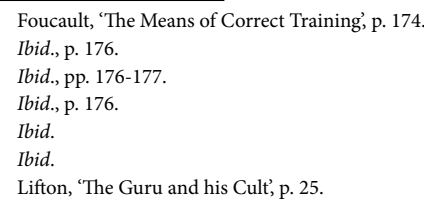


only of the nation's 'best and brightest. ${ }^{97}$ In actuality both groups attracted people from a wide range of backgrounds: those on the 'elite track', university drop outs, doctors, office ladies as well as young people alienated from mainstream society - i.e. almost anyone with a serious concern about Japanese societal and world problems. It was as a result of this fact that the clear status stratification found in both Sekigun and Aum tended to replicate that found in contemporary Japanese society. For instance, those who had graduated from elite universities were most likely to enter into the top strata of Sekigun and Aum Shinrikyo's leadership. Women tended to occupy a lower social status to the men in both movements - however, just as in mainstream society there were of course examples of women improving their social standing in Sekigun and Aum. ${ }^{98}$ On the other hand, those who had little to contribute to the group or the leadership occupied the lowest strata of both organizations - something also mirrored by the contemporary Japanese social order.

\section{Meritocracy and Conformity}

Despite the social stratification found in both groups replicating almost perfectly the type found in Japanese society, there was a certain degree of status mobility built into the hierarchical organizational structures of Sekigun and Aum Shinrikyo. This created a degree of competition between members within each group - in much the same way that the college entrance exam system creates competition among students. To elaborate, just as Japan has sometimes been referred to as a 'super meritocracy ${ }^{39}$ - a meritocracy which is marked by an 'over heating' of the education system as a result of mass competition for limited university places and, by default, limited positions of status - so too did the highly stratified organizational structures of Sekigun and Aum Shinrikyo combined with the opportunity to improve one's status within their respective organizations cultivate competitiveness. Indeed, this competitive atmosphere played a role in the erosion of horizontal relations between members.

Within Sekigun, it was possible to increase one's status by making a satisfactory selfcriticism or by volunteering for dangerous missions thus proving one's commitment to the cause of revolution. An example of this is Okamoto Kozo whose original position within Sekigun was limited to distributing pamphlets for the group. Okamotos status increased, however, after

97 See Steinhoff, 'Hijackers, Bombers and Bank Robbers', p. 725, and Lifton, 'The Guru and his Cult', p. 28

98 For instance Shigenobu Fusako would eventually rise to become leader of a separate branch of Sekigun in Lebanon, dubbed Nihon Sekigun (Japanese Red Army), however, this was helped by the fact that she had not been in Japan at the time of Rengo Sekigun's purge and that much of the core leadership of Sekigun had been previously arrested. See Steinhoff, 'Three Women Who Loved the Left', p. 313. Similarly, in Aum Shinrikyo, Ishii Hisako was the first of Asahara's disciples to receive a holy name and be initiated into the sect's spiritual elite, although some have claimed that this was a result of her sexual relationship with the guru. See Murakami, Underground, p. 291.

99 See for instance Kariya, Taishu Kyoiku shakai no yukue and Yoneyama, The Japanese High School: Silence and Resistance. 
he volunteered for and executed an armed assault on Tel Aviv airport in May $1972 .{ }^{100}$ Similarly, in Aum Shinrikyo one could climb the spiritual ladder by accomplishing the various levels of spiritual practice - indeed, one could be considered 'a god' ${ }^{101}$ simply by attaining what Asahara said were the highest stages of spiritual development. It should be acknowledged that although there was at least the outward appearance of meritocracy in both organizations, 'getting ahead' was largely dependant on one's ability to conform to the ideals of perfection held by those in power. In this regard, life inside the Sekigun mountain hideout or the Aum commune was not so different from life in the outside world.

The mechanisms set in place by both groups to discipline, transform and improve their memberships that would ultimately escalate into violence and torture will now be explored in greater detail.

\section{Communist Transformation}

In order to transform the members of Sekigun and the KAK into a cohesive guerrilla unit devoid of the bourgeois tendencies that had weakened the rest of society, Mori developed the idea of 'communist transformation. ${ }^{102}$ The term had been used previously in Sekigun's theoretical writings ${ }^{103}$ but it had not been made clear as to what methods would be used to achieve this objective. Thus, Mori drew upon a number of sources to formulate the process of communist transformation. These included the self-criticism sessions already used by a number of left-wing groups in the Japanese student movement; ${ }^{104}$ Maoist thought reform $;{ }^{105}$ Feminist consciousness-raising techniques; ${ }^{106}$ and spirit-raising techniques adapted from the Zen Buddhism and bushido ${ }^{107}$ elements of kendo - a traditional form of Japanese fencing practiced by Mori ${ }^{108}$ and many students in Japan today.

Although most in the group wholeheartedly took part in the process of communist transformation in the hope of being challenged and changed as a result, the process was so poorly defined that former members of Sekigun and the KAK often claim never to have fully understood it. ${ }^{109}$ This confusion can be attributed to Mori's own uncertainty and inconsistency over what the method of transformation actually entailed. There was,

\footnotetext{
100 BBC News (Asia-Pacific), 'The Red Army's Reign of Terror'.

101 Lifton, 'Clones of the Guru', p. 92.

102 Lifton, 'A Japanese Phenomenon?', p. 266

103 Mori, Jugekisen to shukusei, p. 10.

104 Steinhoff, op. cit., p. 199

105 Robbins \& Anthony, 'Deprogramming, Brainwashing and Medicalization', p. 284

106 Steinhoff, op. cit., p. 198

107 Literally 'The Way of the Warrior', bushido is the samurai code of ethics and emphasizes, among other things, an unflinching loyalty to the feudal lord or Emperor to the point that one is willing to sacrifice one's own life, by suicide if necessary. See for instance Hurst, "Death, Honor and Loyalty: The Bushido Ideal", pp. 511-527.

108 Lifton, op. cit., p. 266

109 Steinhoff, op. cit., p. 201.
} 
.

however, the vague concept that each member examine their own bourgeois attitudes and behaviour and then eliminate them in order to become a better-prepared revolutionary. This process was accomplished by undergoing a collective examination of each member's weaknesses, followed by individual effort to overcome them. ${ }^{110}$

Compounding the issues arising from the confusion over what communist transformation actually entailed was further ambiguity over what the end result of the process would be. Subsequently, the procedure could easily escalate from collective criticisms of an individual to violent bashings in order to elicit 'honest' self-assessment - as illustrated in the case of Kato and Kojima discussed above. ${ }^{111}$ It was not long before increasingly severe measures were taken against those who were deemed to be making insufficient progress in overcoming their 'bourgeois attitudes' culminating in the eventual torture-killings of twelve of the group's members. ${ }^{112}$

The notion that one can be 'toughened up' through physical beatings is not a peculiarity of Sekigun, however. Indeed, such practices can still be found in sporting clubs in Japan today. ${ }^{113}$ As a member of a kendo club Mori's methods of disciplining and 'toughening up' his comrades certainly appear to have reflected the sort of training and disciplining he himself possibly would have received as a kendo club member.

\section{Defining 'bourgeois tendencies'}

Confusion also appears to have arisen over what was deemed to be bourgeois attitudes and behaviour. Mori's concept of what constituted 'bourgeois tendencies' or 'ideological deviation' appears to have been simplistically drawn from traditional notions of evil such as greed, envy and self-indulgence. ${ }^{114} \mathrm{~A}$ typical example of what Mori considered to be bourgeois behaviour was illustrated in his reaction to one Sekigun member who asked for a tissue whilst warming himself in his sleeping bag. This was viewed as a form of self-indulgence as well as a deviation from Sekigun's ideology. Accordingly, the individual was beaten for his lack of revolutionary spirit in an effort to toughen him up. ${ }^{115}$ On the other hand, those who had been part of the KAK viewed sexual thoughts and behaviour as a sign of bourgeois inclinations. This stemmed from the KAK's original Marxist-Feminist ideological position, which held that revolution must be achieved before women can be liberated. ${ }^{116}$ The KAK members had on several occasions brought

110 Ibid., p. 199.

111 Lifton, op. cit., p. 266

112 Kuriyama, 'Terrorism at Tel Aviv', p. 344.

113 See for instance, Yoneyama, "Control: The Structure of Silence" in The Japanese High School: Silence and Resistance, pp. 94-102.

114 Steinhoff, op. cit., p. 201.

115 Kuriyama, op. cit., p. 344.

116 Steinhoff, op. cit., p. 202. 
Sekigun's mainly male membership to task over what they deemed to be their 'backward bourgeois mentality' regarding women. ${ }^{117}$

Thus, a situation arose where although each member entered willingly into a process that was designed to stimulate self-improvement, the details of what such a process entailed were poorly defined. While some members might have been able to satisfy Mori by making what he deemed to be an adequate sokatsu, others - perhaps confused over what was being asked of them or by what constituted a confessable offence - would be beaten until they had made a satisfactory self-examination. Equally, those that were deemed to be displaying signs of weakness were also beaten.

Aum Shinrikyo was able to avoid some of the problems experienced by Sekigun which had arisen out of confusion over ideology thanks in part to Asahara's conception of a 'stage' process towards spiritual liberation. That, however, did not ensure that the path towards becoming a spiritual elite was not a violent one. Indeed, in Aum Shinrikyo as in Sekigun, the line between training and discipline often blurred ${ }^{118}$ as will now be discussed in detail.

\section{Dropping Karma - Transcendence and Torture in Aum Shinrikyo}

A key aspect taken from Buddhist teachings and integrated into Aum's own belief system was the notion that the physical body had to be purified of bad karma - the accumulated debt of past wrong doings which was the source of suffering in one's current lifetime. ${ }^{119}$ This purification process entailed the undertaking of severe physical austerities and other extreme practices. It was believed that the physical body was an impediment to the attainment of higher levels of spiritual consciousness - a polluted entity whose influences had to be cast off so that the spirit could attain gedatsu (liberation). ${ }^{120}$ According to Asahara it was due to one's clinging attachment to the polluted physical body that one acquired the negative karma which dragged the spirit down into hell after death; gedatsu came from eradicating such attachments to the material body via asceticism. ${ }^{121}$

Another aspect of Buddhism adopted by Aum was its doctrinal position which held that suffering was a product of materialism and desire - this was why there was so much suffering within Japan's materialistic culture. However, Asahara also believed 
.n.m.n. of

that suffering was an incentive to spiritual practice and a key to attaining gedatsu. Subsequently, Asahara proclaimed that one 'needed' to suffer in order to achieve liberation and to develop one's commitment and faith - this was why, he argued, that rigorous, even violent, ascetic practices would have to be engaged in if one hoped to forcibly remove bad karma and attain gedatsu. ${ }^{122}$ Accordingly, Aum developed increasingly harsh methods such as the Black Box solitary confinement training and the inverted suspension procedure discussed previously which were supposedly designed to help disciples to 'drop karma' and attain higher states of liberation. Just as was the case for members of Sekigun though, Aum disciples often quite willingly subjected themselves to these austere practices in order to achieve the types of spiritual powers that Asahara professed to possess and to create a Utopian society - in order to become an 'evolved being ${ }^{123}$ one had to undergo the harshest possible training. ${ }^{124}$ The willingness of Aum's disciples' to subject themselves to seemingly death-defying ascetic practices is exemplified by those who meditated underground for several days without food or water. ${ }^{125}$

\section{Training as Punishment}

The accumulation of bad karma was also viewed to be a result of committing wrong deeds. Subsequently, procedures which had been developed as a method of negating bad karma were similarly utilized as a form of punishment for transgressing Aum restrictions. Practices such as inverted suspension were prescribed by Asahara as a consequence of what he deemed to be 'grave karmic sins. ${ }^{126}$ Thus, inverted suspension was considered 'therapeutic' in the sense that it was a means of forcibly removing bad karma. ${ }^{127}$

In both groups, the methods adopted to improve the quality of their members escalated into torture and killing. The rationale behind using such severe disciplining methods, however, was that it was regarded as a necessary evil in order to overcome the types of individual personal flaws which had led to the larger 'failure' of Japanese society. To be sure, in both groups the act of 'personal struggle' became an intrinsic part of individual improvement. However, the restrictions placed on members within both organizations and the punishments dealt out for transgressing these restrictions were in many cases far more oppressive and severe than the laws and punishments found in Japanese society.

123 Iwai (pseudonym) quoted in Lifton, 'Forcing the End', p. 76.

124 Ibid., p. 77.

125 Documented in 'Aum Supreme Truth', Foreign Correspondent, ABC.

126 Reader, 'A Death in the Culture of Coercive Asceticism', p. 16.

127 Ibid. 


\section{Ultra-Elitism}

Extreme competitiveness combined with constant pressure to conform - traits of social organizations such as Sekigun and Aum also tend to foster a culture of extreme elitism. In the case of these groups this tendency was only compounded by the fact that the leadership of Sekigun and Aum Shinrikyo consisted predominantly of university students and graduates who perhaps took their leadership roles for granted, naturally assuming that they should also be entrusted as the leaders after establishment of a new social order. ${ }^{128}$ Indeed, the perception emerged among members of both groups that they constituted an elite class of individuals who, as a result of their training, had 'earned' the right to lead - even to the extent that they felt justified in deciding who should be allowed to live in the ideal societies they hoped to create. Moreover, this sort of logic was also employed to rationalize the torture-killings of people inside both groups; individuals such as Sekigun's Ozaki Atsuo who did not survive beatings intended to toughen him up and Majima Terayuki who died during austerities designed to help him reach a higher spiritual level were too weak to live in the new world.

\section{Concluding comments}

Throughout this article there has been one recurring theme: that both Sekigun and Aum Shinrikyo replicated the very aspects of Japanese society they were critical of, which constituted, in their opposition, their raison d'etre, their motivation to be different and to strive for their cause. Sekigun emerged to resist what its members saw to be the autocratic, authoritarian power of the Japanese state. Their members opposed the power structures which in their view existed solely to oppress and exploit the lower classes whilst benefiting society's elite members of the ruling 'bourgeoisie' class. Thus, theoretically, their fundamental ideological inclination was towards the pursuit of greater social equality and freedom from the oppressive, authoritarian state. Aum Shinrikyo, on the other hand, was established by those who supposedly opposed the emptiness created by the materialism, competitiveness and social stratification of contemporary Japan.

Sekigun and Aum Shinrikyo were formed by individuals who had rejected Japanese society and its institutions. Their very rejection of the prevailing social structure was the impetus for creating new social organisations which would be devoid of the social ills that had in their view corrupted Japan. The societies they hoped to create then could be regarded as the antithesis of Japanese society. Yet both Sekigun and Aum Shinrikyo ultimately replicated the same sort of hierarchical organizational

128 Kuriyama, op. cit., p. 339 . 
structure which existed in Japan in their respective eras and subsequently the very same social stratification, high status consciousness and competitiveness which such a system inevitably produces. Despite efforts by both groups to create the antithesis to everything they rejected within the Japanese society of their times, they paradoxically reproduced and magnified within their own social organizations the least desirable societal traits of elitism, exclusivity and conformity using the most extreme measures to discipline and control their members to fit each groups' respective notions of the ideal individual.

Foucault's earlier work The Thought from Outside ${ }^{129}$ gives us an understanding of the nature of order and why attempts to bring about a new order are doomed to replicate the same sort of power structure: 'Anyone who attempts to oppose the law in order to found a new order, to organise a second police force, to institute a new state, will only encounter the silent and infinitely accommodating welcome of the law. ${ }^{130}$ In other words, any new system based on the same notion of power will inevitably produce similar social institutions. The cases of Sekigun and Aum Shinrikyo examined in this paper present quintessence of this reality; their inescapable dilemma represents their failure to envisage their ideal society on a new paradigm. It signifies the paradox that they were the changelings of the very society they detested, denounced, and wanted to destroy.

\section{References}

Barker, P., Michel Foucault - An Introduction (Edinburgh: Edinburgh University Press, 1998).

BBC News (Asia-Pacific), ‘The Red Army’s Reign of Terror', 8 November 2000.

Bestor, T. C., 'Conflict, Legitimacy and Tradition in a Tokyo Neighbourhood' in Kraus E. S., et al (eds.), Conflict in Japan (Honolulu: University of Hawaii Press, 1984).

Cutts, R. L., An Empire of Schools - Japan's Universities and the Moulding of a National Power Elite (New York: M.E. Sharpe, 1997).

Foreign Correspondent, 'Aum Supreme Truth', ABC, 23 June 1995.

Foucault, M., Discipline and Punish: The Birth of the Prison (New York: Vintage Books, 1977).

Foucault, M., 'The Thought from Outside' in Foucault, Blanchot (New York: MIT Press, 1987).

Fuse T., 'Student Radicalism in Japan: A 'Cultural Revolution'?', in Comparative Education Review, Vol. 13, No. 3, (Oct, 1969), pp. $325-342$

Hurst, G. C., 'Death, Honor and Loyalty: The Bushido Ideal', Philosophy East and West, Vol. 40, No. 4, Understanding Japanese Values. (Oct., 1990), pp. 511-527.

129 Foucault, 'The Thought from Outside', p. 38.

130 Ibid. 
Igarashi, Y., 'Dead Bodies and Living Guns: The United Red Army and Its Deadly Pursuit of Revolution,1971-1972', in Japanese Studies, Vol. 27, No. 2. (September 2007), pp. 119-137.

Ishida, T., 'Conflict and Its Accommodation: Omote-Ura and Uchi-Soto Relations' in Kraus, E. S., et al (eds.), Conflict in Japan (Honolulu: University of Hawaii Press, 1984).

Kariya, T., Taishu Kyoiku shakai no yukue (Tokyo: Chuokoron, 1995).

Kuriyama, Y., 'Terrorism at Tel Aviv Airport and a New Left Group in Japan', in Asian Survey, Vol. 13, No. 3, (March, 1973), pp. $336-346$.

Lifton, R. J., Destroying the World to Save It: Aum Shinrikyo, Apocalyptic Violence and the New Global Terrorism (New York: Metropolitan Books, 1999).

March, R. M., 'Safe No More - Aum Shinrikyo, the 1995 Sarin Gas Attacks, and the Future of Japanese Society', in Working Paper University of Western Sydney, (Nepean Dept. of Marketing: New South Wales, 1996-1997).

Matraux, D. A., 'Religious Terrorism in Japan: The Fatal Appeal of Aum Shinrikyo' in Asian Survey, Vol. 35, No. 12, (December 1995), pp. 1140 - 1154.

McCormack, G. and Box, M., “Terror in Japan”, Japan Focus. Retrieved 1 June 2007, from http://www.japanfocus.org/ products/details/1570.

Mohwald, U., 'Social Stratification', in Kreiner, J., Mohwald U. and Olschleger H.D., (eds.), Modern Japanese Society (Boston, Leiden: Brill, 2004).

Mori, T., Jugekisen to shukusei (Tokyo: Shigenchosa, 1984).

Murakami, H., Underground - The Tokyo Gas Attack and the Japanese Psyche (London: Vintage, 2003).

Olson, L., 'Takeuchi Yoshimi and the Vision of a Protest Society in Japan', Journal of Japanese Studies, Vol. 7, No. 2, (Summer, 1981), pp. $319-348$.

Reader, I., A Poisonous Cocktail? Aum Shinrikyo's Path to Violence (Copenhagen: NIAS Books, 1996).

Reader, I., Religious Violence in Contemporary Japan: The Case of Aum Shinrikyo (Great Britain: Curzon Press, 2000).

Robbins, T. and Anthony, D., 'Deprogramming, Brainwashing and the Medicalization of Deviant Religious Groups', Social Problems, Vol. 29, No. 3, (February: 1982).

Rohlen, T. P., 'The Education of the Japanese Banker' in Okimoto, D. I. and Rohlen, T. P. (eds.), Inside the Japanese System, Readings on Contemporary Society and Political Economy (Stanford: Stanford University Press, 1988).

Sakurai, T., 'The Generation Gap in Japanese Society since the 1960s' in Mathews, G. and White, B., (eds.), Japan's Changing Generations: Are Young People Creating a New Society (London: Routledge Curzon, 2004).

Shimazono, S., 'The Evolution of Aum Shinrikyo as a Religious Movement' in Kisala, R. J. and Mullins, M. R. (eds.), Religion and Social Crisis in Japan: Understanding Japanese Society through the Aum Affair (Great Britain: Palgrave Publishers Ltd., 2001).

Steinhoff, P. G., 'Portrait of a Terrorist: An Interview with Kozo Okamoto', Asian Survey, Vol. 16, No. 9 (Sep., 1976), pp. 830 - 845. 
.n.m.n.m \&

Steinhoff, P. G., "Student Conflict" in Kraus, E. S., et al (eds.), Conflict in Japan (Honolulu: University of Hawaii Press, 1984).

Steinhoff, P. G., 'Hijackers, Bombers and Bank Robbers: Managerial Style in the Japanese Red Army', in The Journal of Asian Studies, Vol. 48, No. 4, (Nov., 1989), pp. 724 - 740.

Steinhoff, P. G., 'Death by Defeatism and Other Fables: The Social Dynamics of the Rengo Sekigun Purge', in Sugiyama Lebra, T. (ed.), Japanese Social Organization (Honolulu: University of Hawaii Press, 1992).

Steinhoff, P. G., 'Three Women Who Loved the Left: Radical Woman Leaders in the Japanese Red Army Movement' in Imamura, A. E. (ed.), Re-Imagining Japanese Women (Berkley: University of California Press, 1996).

Sugimoto, Y., An Introduction to Japanese Society (Cambridge: Cambridge University Press, 1997).

Vogel, E. F.., Japan's New Middle Class, The Salaryman and His Family in a Tokyo Suburb, (California: University of California Press, 1971).

Yoneyama, S., The Japanese High School: Silence and Resistance (London: Routledge Press, 1999). 